\title{
Health education as a strategy for the promotion of the health of the elderly: an integrative review
}

\author{
Cícera Amanda Mota Seabra' ID \\ Samyra Paula Lustoza Xavier ${ }^{2}$ (D) \\ Yana Paula Coêlho Correia Sampaio ${ }^{3}$ ID \\ Mirna Fontenele de Oliveira ${ }^{4}$ (DD \\ Glauberto da Silva Quirino $0^{5}$ \\ Maria de Fátima Antero Sousa Machado 5 (D)
}

\section{Abstract}

Objective: To identify the key issues and health education strategies for the health promotion for the elderly. Method: An integrative literature review was conducted during the months of March and April 2018, by means of the Virtual Health Library, in the Medical Literature Analysis and Retrieval System Online, Latin American Literature in Health Sciences and the Scientific Electronic Library Online databases. After the search process and the selection of publications, the final sample consisted of 24 articles. Results: A total of 16 Brazilian articles, the majority of which were carried out in the southeast and south of the country, were identified, in which the most frequently expressed themes for the health education of the elderly were healthy eating and physical exercise practices. Conclusion: The actions of education in health were focused on healthy eating and physical activity, carried out by means of group workshops, seminars and/or lectures, performed, in the majority, by nurses and community health agents who were part of family health teams.
Keywords: Health Promotion. Health Education. Health of the Elderly.

1 Universidade Regional do Cariri (URCA), Rede Nordeste de Formação em Saúde da Família (RENASF), Programa de Pós-graduação em Saúde da Família. Crato, CE, Brasil.

2 Universidade Regional do Cariri (URCA), Departamento de Enfermagem. Iguatu, CE, Brasil.

3 Faculdade de Medicina Estácio de Juazeiro do Norte, Eixo Saúde da Família. Juazeiro do Norte, CE, Brasil.

4 Universidade Federal do Cariri (UFCA), Coordenadoria de Qualidade de Vida no Trabalho/Pro-Reitoria de Gestão de Pessoas. Juazeiro do Norte, CE, Brasil.

5 Universidade Regional do Cariri (URCA), Departamento de Enfermagem. Crato, CE, Brasil.

The authors declare that there are no conflicts of interest in relation to this study.

No funding was provided for this study.

Correspondence

Cícera Amanda Mota Seabra 


\section{INTRODUCTION}

Health education is understood as an educational process of knowledge construction, aimed at the appropriation of the theme by the population ${ }^{1}$. It refers to a set of practices that contribute to the increase of the individual and collective autonomy of people and the debate with health professionals and managers in order to achieve health care based on the needs of individuals and communities, improving the quality of life and health of the population ${ }^{2,3}$.

As an emancipatory pedagogical process, health education favors the development of intellectual autonomy, becoming an imperative tool to promote the improvement of the quality of life and health of the elderly ${ }^{4,5}$.

Primary Health Care (PHC), of which the main care scenario is the Family Health Strategy (FHS), is a privileged locus of educational practices in health, and as the integrated work of the team of health professionals, favors and mobilizes efforts to contribute to the maintenance of individual and collective health ${ }^{6}$, which can favor critical and transformative awareness, allowing the exercise of citizenship and effecting personal and social changes.

Therefore, primary care health professionals have the important role of promoting health education programs and activities, aimed at the quality of life of individuals and families, and these actions should be integrated into care ${ }^{7}$. To achieve this, such actions should be planned and directed at the appropriate target population, articulated by a multiprofessional team and executed on a permanent basis, considering what the subjects need and want to know to promote their health ${ }^{8}$.

The theme in question is highlighted in the research priorities agenda of the Ministry of Health medical opinion report for the year 2018, since it encourages the evaluation of the implementation of health education strategies in the Unified Health System (or SUS); the surveying of innovative, participatory and resolutive methodologies of health education with the elderly; and the assessment of the impact of health education practices with elderly persons in primary care?
The importance of the theme is therefore clear, both in terms of the performance of care practices and in a research setting; while it is believed that promoting health education actions with the elderly, with their participation and that of their families and the community, is an effective method for promoting the health and quality of life of this population. Thus, it is necessary to broaden knowledge about this theme.

From this perspective, the present study aimed to identify the main themes and strategies of health education for the promotion of the health of the elderly.

\section{METHOD}

An integrative literature review was performed. To construct the study, six fundamental steps were followed: identification of the theme and selection of the research question; establishment of inclusion and exclusion criteria for studies; categorization of studies; evaluation of studies; interpretation of results and synthesis of knowledge ${ }^{10}$.

To conduct the research, the following guiding question was elaborated: What are the main strategies used and the themes approached in bealth education actions, with a view to bealth promotion aimed at the elderly population?

From the guiding question, in order to facilitate the definition of the descriptors, we used the PVO strategy (Population, Variable of interest and Outcome), which defined the study population as "the elderly", the variable of interest as "health education" and the outcome as "health promotion".

The searches were performed between March and April 2018 by two independent evaluators, through the Virtual Health Library, in the Medical Literature Analyzes and Retrieval System Online (MEDLINE), Latin American and Caribbean Saúde (LILACS) and the Scientific Electronic Library Online (SciELO) databases. These choices were justified by their scientific scope in relation to research in the field of health promotion.

For the searches, the following controlled descriptors were selected: "Health of the Elderly", 
"Health Education" and "Health Promotion", which were crossed with the help of the Boolean operator AND, using the advanced search method from categorization by title, abstract and subject.

The following inclusion criteria were chosen: studies whose theme was related to health education with the elderly in article format and available for download, in English, Portuguese and Spanish, with a year of publication between 2013 and 2017. This time frame was chosen because Decree No. 8.114, which deals with the National Commitment to Active Aging $^{11}$, which includes health education actions, was published in 2013. The following exclusion criteria were selected: studies in the form of dissertations, theses, reflection and literature review articles, documentaries, essays and/or reviews.

The database search revealed 35,211 studies, of which, 2,439 articles were found in LILACS, 32,157 in MEDLINE and 615 in SciELO.

Following the application of the filters, the next step was to select the papers from the reading of titles and abstracts, from which those that did not explicitly fit the scope of this research were excluded. A total of 64 potentially eligible articles were identified were then read in full. At this stage, three repeated articles were excluded, as well as 12 articles which were not suitable for the theme; three literature reviews; three reflection articles and 19 articles that were not available for download, resulting in a total of 24 studies included in the final sample.

The evaluation stage of the studies allowed us to identify that according to the evidence pyramid ${ }^{12}$ two studies were classified as being of the second level, or clinical trials; one was third level, which was a cohort study; one was the fourth level, a casecontrol study; five were level five, characterized as quasi-experimental studies, and 15 had a scientific evidence level of six, which represent descriptive studies.

For data extraction, a form was developed containing bibliometric data about the articles studied, summarized in Chart 1 , as well as information regarding the pedagogical strategies used, the professionals involved and the results obtained in health education, which are presented descriptively in the following sections.

\section{RESULTS}

Considering the variables selected for the presentation of the articles, Chart 1 summarizes the following studied aspects: authors, year, place, type of study, sample and study objectives.

Chart 1. Description of selected articles by authors, year and location, type of study, sample and study objectives.

\begin{tabular}{|l|l|l|l|}
\hline Authors & $\begin{array}{l}\text { Year and } \\
\text { Location }\end{array}$ & $\begin{array}{l}\text { Type of Study and } \\
\text { Sample }\end{array}$ & Objectives of Study \\
\hline $\begin{array}{l}\text { Mendonça et } \\
\text { al. }\end{array}$ & $\begin{array}{l}\text { 2013, } \\
\text { Viçosa, } \\
\text { Minas Gerais, } \\
\text { Brazil }\end{array}$ & $\begin{array}{l}\text { Experience report/ } \\
\text { 20 elderly persons }\end{array}$ & $\begin{array}{l}\text { Report a working experience with the elderly and } \\
\text { support a critical-theoretical reflection on the practice } \\
\text { of educational workshops as a health education strategy, } \\
\text { in the light of Freire's thinking, based on the use of } \\
\text { participatory methodologies. }\end{array}$ \\
\hline $\begin{array}{l}\text { Nogueira et } \\
\text { l. }^{14}\end{array}$ & $\begin{array}{l}\text { 2013, } \\
\text { Goiânia, } \\
\text { Goias, } \\
\text { Brazil }\end{array}$ & $\begin{array}{l}\text { Qualitative research/23 } \\
\text { elderly persons and } \\
\text { six community health } \\
\text { agents }\end{array}$ & $\begin{array}{l}\text { To identify therapeutic factors present in the health } \\
\text { promotion group of elderly persons. }\end{array}$ \\
\hline Evers et al. ${ }^{15}$ & $\begin{array}{l}2013, \\
\text { Australia }\end{array}$ & $\begin{array}{l}\text { Cohort/710 elderly } \\
\text { persons }\end{array}$ & $\begin{array}{l}\text { Conduct a multifaceted assessment of a social marketing } \\
\text { campaign to raise asthma awareness among elderly } \\
\text { persons in a regional Australian community. }\end{array}$ \\
\hline $\begin{array}{l}\text { Bhurosy and } \\
\text { Jeewon }{ }^{16}\end{array}$ & $\begin{array}{l}\text { 2013, } \\
\text { Mauritius, } \\
\text { East Africa }\end{array}$ & $\begin{array}{l}\text { Experimental model/80 } \\
\text { people aged } 40 \text { or over }\end{array}$ & $\begin{array}{l}\text { To evaluate the effectiveness of a theory-based } \\
\text { educational intervention to improve calcium intake, self- } \\
\text { efficacy, and knowledge of older Mauritians. }\end{array}$ \\
\hline
\end{tabular}


Continuation of Chart 1

\begin{tabular}{|c|c|c|c|}
\hline Authors & $\begin{array}{l}\text { Year and } \\
\text { Location }\end{array}$ & $\begin{array}{l}\text { Type of Study and } \\
\text { Sample }\end{array}$ & Objectives of Study \\
\hline $\begin{array}{l}\text { Chung and } \\
\text { Chung }^{17}\end{array}$ & $\begin{array}{l}2014, \\
\text { Hong Kong }\end{array}$ & $\begin{array}{l}\text { Experimental study } / 60 \\
\text { elderly persons }\end{array}$ & $\begin{array}{l}\text { Evaluate a three-week program that includes culinary } \\
\text { demonstrations with free food samples to motivate older } \\
\text { adults to cook more and improve their nutritional status. }\end{array}$ \\
\hline Ferreti et al. ${ }^{18}$ & $\begin{array}{l}2014 \\
\text { Chapecó, } \\
\text { Santa Catarina, } \\
\text { Brazil }\end{array}$ & $\begin{array}{l}\text { Qualitative research/ } \\
\text { seven elderly persons }\end{array}$ & $\begin{array}{l}\text { To verify the impact of a health education program on } \\
\text { the knowledge of elderly persons about cardiovascular } \\
\text { diseases. }\end{array}$ \\
\hline $\begin{array}{l}\text { Janini et } \\
\text { al. }^{19}\end{array}$ & $\begin{array}{l}2015 \\
\text { Rio de Janeiro, } \\
\text { Brazil }\end{array}$ & $\begin{array}{l}\text { Qualitative research } / 83 \\
\text { elderly persons }\end{array}$ & $\begin{array}{l}\text { To analyze the impact of health promotion and education } \\
\text { actions in the search for quality of life, autonomy and } \\
\text { self-care of the elderly. }\end{array}$ \\
\hline Sink et al. ${ }^{20}$ & 2015, USA & $\begin{array}{l}\text { Randomized clinical } \\
\text { study/ } \\
1,635 \text { participants }\end{array}$ & $\begin{array}{l}\text { Determine whether a } 24 \text {-month physical activity } \\
\text { program results in better cognitive function, lower risk } \\
\text { of mild cognitive impairment (MCI) or dementia, or } \\
\text { both, compared to a health education program. }\end{array}$ \\
\hline $\begin{array}{l}\text { Machado et } \\
\text { al. }{ }^{21}\end{array}$ & $\begin{array}{l}2015, \\
\text { Minas Gerais, } \\
\text { Brazil }\end{array}$ & $\begin{array}{l}\text { Convergence } \\
\text { research } / 21 \text { elderly } \\
\text { persons and nine health } \\
\text { professionals }\end{array}$ & $\begin{array}{l}\text { Describe the stages of the empowerment process of an } \\
\text { elderly group in a rural community. }\end{array}$ \\
\hline $\begin{array}{l}\text { Almeida et } \\
\text { al. } .^{22}\end{array}$ & $\begin{array}{l}2015, \\
\text { Viçosa, } \\
\text { Minas Gerais, } \\
\text { Brazil }\end{array}$ & $\begin{array}{l}\text { Intervention study/82 } \\
\text { participants }\end{array}$ & $\begin{array}{l}\text { Analyze possible changes that have occurred } \\
\text { in anthropometric measurements and levels of functional } \\
\text { physical fitness of elderly persons participating in a } \\
\text { community intervention project. }\end{array}$ \\
\hline $\begin{array}{l}\text { Caprara, et } \\
\text { al. } .^{23}\end{array}$ & $\begin{array}{l}\text { 2015, Madrid, } \\
\text { Spain }\end{array}$ & $\begin{array}{l}\text { Quantitative study/73 } \\
\text { participants }\end{array}$ & $\begin{array}{l}\text { Testify to the effectiveness of Vital Aging-Multimedia, } \\
\text { a psychoeducational multimedia program designed to } \\
\text { promote successful aging. }\end{array}$ \\
\hline $\begin{array}{l}\text { Sousa and } \\
\text { Oliveira }^{24}\end{array}$ & $\begin{array}{l}2015, \\
\text { Braga, } \\
\text { Portugal }\end{array}$ & $\begin{array}{l}\text { Intervention study/25 } \\
\text { elderly persons }\end{array}$ & $\begin{array}{l}\text { Contribute to the active aging of day/social centers } \\
\text { for elderly persons, harmoniously developing all } \\
\text { its dimensions, aiming to make users autonomous, } \\
\text { participatory and active. }\end{array}$ \\
\hline $\begin{array}{l}\text { Cecílio and } \\
\text { Oliveira }^{25}\end{array}$ & $\begin{array}{l}2015, \\
\text { Limeira, Sao } \\
\text { Paulo, } \\
\text { Brazil }\end{array}$ & $\begin{array}{l}\text { Intervention study/23 } \\
\text { elderly persons }\end{array}$ & $\begin{array}{l}\text { Promote, through Nutrition Education activities, healthy } \\
\text { eating habits in a group of institutionalized elderly } \\
\text { persons. }\end{array}$ \\
\hline Luten et al. ${ }^{26}$ & $\begin{array}{l}2015, \\
\text { Groningen, } \\
\text { Holland }\end{array}$ & $\begin{array}{l}\text { Quasi-experimental } \\
\text { study/ } \\
564 \text { elderly persons }\end{array}$ & $\begin{array}{l}\text { To assess the range and effects of short and medium } \\
\text { term intervention (with local media campaign and } \\
\text { environmental approaches) on physical activity and } \\
\text { healthy eating in elderly persons in a socioeconomically } \\
\text { disadvantaged community compared with a control group. }\end{array}$ \\
\hline $\begin{array}{l}\text { Lucena et } \\
\text { al. }^{27}\end{array}$ & $\begin{array}{l}2016, \\
\text { João Pessoa, } \\
\text { Paraiba, Brazil }\end{array}$ & $\begin{array}{l}\text { Experience report/99 } \\
\text { elderly persons }\end{array}$ & $\begin{array}{l}\text { Describe a report of health education practices of a } \\
\text { university extension project, encouraging the adoption of } \\
\text { preventive measures of self-care in relation to the health } \\
\text { of the elderly. }\end{array}$ \\
\hline $\begin{array}{l}\text { Munhoz et } \\
\text { al. }\end{array}$ & $\begin{array}{l}2016, \\
\text { Santa Maria, } \\
\text { Rio Grande do } \\
\text { Sul, } \\
\text { Brazil }\end{array}$ & $\begin{array}{l}\text { Experience report/144 } \\
\text { elderly persons }\end{array}$ & $\begin{array}{l}\text { Report the experience of members of the Nursing } \\
\text { Tutorial Education Program in the "Acampavida" } \\
\text { extension project, held annually with elderly persons, } \\
\text { through health education activities. }\end{array}$ \\
\hline
\end{tabular}


Continuation of Chart 1

\begin{tabular}{|c|c|c|c|}
\hline Authors & $\begin{array}{l}\text { Year and } \\
\text { Location }\end{array}$ & $\begin{array}{l}\text { Type of Study and } \\
\text { Sample }\end{array}$ & Objectives of Study \\
\hline $\begin{array}{l}\text { Barbosa et } \\
\text { al. }^{29}\end{array}$ & $\begin{array}{l}2016, \\
\text { Recife, } \\
\text { Pernambuco, } \\
\text { Brazil }\end{array}$ & $\begin{array}{l}\text { Experience report } / 30 \\
\text { participants }\end{array}$ & $\begin{array}{l}\text { Report the interdisciplinary experiences in the Family } \\
\text { Health Strategy (FHS) with a Group of Elderly persons, } \\
\text { through the Education Program for Health Work (or } \\
\text { PET-Health) developed at the Federal University of } \\
\text { Pernambuco (UFPE). }\end{array}$ \\
\hline $\begin{array}{l}\text { Nascimento } \\
\text { and Ramos }\end{array}$ & $\begin{array}{l}2016, \\
\text { Petrolina, } \\
\text { Pernambuco, } \\
\text { and Juazeiro, } \\
\text { Bahia, } \\
\text { Brazil }\end{array}$ & $\begin{array}{l}\text { Experience report/150 } \\
\text { elderly persons }\end{array}$ & $\begin{array}{l}\text { Present the set of activities developed weekly by } 10 \\
\text { medical students from the Federal University of Vale } \\
\text { do São Francisco in Pernambuco with groups of elderly } \\
\text { persons from the Active Life Program (ALP) and the } \\
\text { Open University for the Elderly (UNATI/Univasf). }\end{array}$ \\
\hline Lopes et al. ${ }^{31}$ & $\begin{array}{l}2016, \\
\text { Florianópolis, } \\
\text { Santa Catarina, } \\
\text { Brazil }\end{array}$ & $\begin{array}{l}\text { Qualitative research/69 } \\
\text { people }\end{array}$ & $\begin{array}{l}\text { Verify the most relevant pedagogical aspects of a physical } \\
\text { exercise class for the adoption of and permanence in } \\
\text { physical activity programs in the perception of long-lived } \\
\text { elderly women. }\end{array}$ \\
\hline Sá et al. ${ }^{32}$ & $\begin{array}{l}2016, \\
\text { Diamantina, } \\
\text { Minas Gerais, } \\
\text { Brazil }\end{array}$ & $\begin{array}{l}\text { Quantitative } \\
\text { research/28 participants }\end{array}$ & $\begin{array}{l}\text { Identify and describe health promotion actions related } \\
\text { to the physical activity of elderly persons in basic health } \\
\text { units, as well as the perception of those responsible for } \\
\text { this practice. }\end{array}$ \\
\hline Jih et al..$^{33}$ & $\begin{array}{l}2016, \\
\text { São Francisco, } \\
\text { California, } \\
\text { USA }\end{array}$ & $\begin{array}{l}\text { Randomized group } \\
\text { study/756 elderly } \\
\text { persons }\end{array}$ & $\begin{array}{l}\text { To compare the effects of two types of intervention: } \\
\text { lectures and Chinese printed materials versus solely } \\
\text { Chinese printed materials on knowledge and adherence } \\
\text { to nutrition and physical activity guidelines among older } \\
\text { Chinese immigrants in San Francisco, California. }\end{array}$ \\
\hline $\begin{array}{l}\text { Amthauer } \\
\text { and Falk }\end{array}$ & $\begin{array}{l}2017, \\
\text { Porto Alegre, } \\
\text { Rio Grande do } \\
\text { Sul, } \\
\text { Brazil }\end{array}$ & $\begin{array}{l}\text { Qualitative research/16 } \\
\text { professionals }\end{array}$ & $\begin{array}{l}\text { Identify the actions and practices performed by health } \\
\text { professionals with elderly persons seeking care in a Basic } \\
\text { Health Unit }\end{array}$ \\
\hline $\begin{array}{l}\text { Mendonça et } \\
\text { al. }^{35}\end{array}$ & $\begin{array}{l}2017, \\
\text { Uberaba, } \\
\text { Minas Gerais, } \\
\text { Brazil }\end{array}$ & $\begin{array}{l}\text { Action Research / } \\
98 \text { health professionals }\end{array}$ & $\begin{array}{l}\text { To evaluate the development and implementation of a } \\
\text { continuing education action directed to primary care } \\
\text { professionals on the theme "health education groups } \\
\text { with elderly persons". }\end{array}$ \\
\hline Santos et al. ${ }^{36}$ & $\begin{array}{l}\text { 2017, Quixadá, } \\
\text { Ceará, Brazil }\end{array}$ & $\begin{array}{l}\text { Experience report/22 } \\
\text { elderly persons }\end{array}$ & $\begin{array}{l}\text { Report the experience of the perception of students } \\
\text { about health education actions aimed at elderly persons } \\
\text { of the Remanso da Paz shelter in Quixadá, Ceará. }\end{array}$ \\
\hline
\end{tabular}

The themes addressed in the health education actions were varied, however, there was a predominance of discussions about healthy eating $17,20,22,25,26,28,29,33,35$ and the practice of physical exercises $^{20,22,26,28,31,32,34,35}$. The other themes included chronic diseasses ${ }^{18,19,27,36}$ with emphasis on arterial hypertension ${ }^{18,27,36}$; diabetes melitus ${ }^{18,27,36}$; respiratory diseases $^{15}$; sexuality ${ }^{28,30}$; active aging ${ }^{30}$; healthy habits $^{21,23,35}$; medication ${ }^{13,36}$; legal and financial questions $^{20,28}$; and social participation ${ }^{23,24}$.
These actions were developed by health professionals, mostly primary care workers; with the participation of community health agents ${ }^{14,21,34,35}$, nurses $^{34,35}$, nursing technicians ${ }^{21,32,34}$, doctors ${ }^{34}$ and dental surgeons ${ }^{35}$. Only one article ${ }^{19}$ did not specify the professional category.

In many studies, the actions were performed by students and teachers from various undergraduate courses, especially Nursing ${ }^{13,27,28}$, followed by 
other courses, which appeared less frequently, such as: Medicine ${ }^{27,30}$, Physical Education ${ }^{22,32}$, Nutrition $^{22,29}$, Pharmacy $^{36}$, Occupational Therapy ${ }^{29}$ and Physiotherapy ${ }^{32}$.

In terms of the strategies adopted for the application of health education activities, nine studies used group workshops ${ }^{13,20-22,27-29,32,34}$; five used seminars and/or lectures ${ }^{17,19,30,33,36}$; three made use of expository, dynamic and informal conversations ${ }^{18,25,30}$; two applied dialogued exposition ${ }^{16,24}$; marketing campaigns ${ }^{15,26}$ and digital education ${ }^{23}$. Three studies did not mention the strategies adopted ${ }^{14,31,35}$.

As a theoretical framework for conducting the studies, two ${ }^{13,27}$ were based on the work of Paulo Freire. Many articles, although not mentioning the subject directly, spoke about health education with a participatory and dialogical approach, aiming at the empowerment of the subject, which is consistent with Freirean thinking ${ }^{18,22,25,28,30,35}$. The other references were the National Health Promotion Policy ${ }^{19}$, a belief in health model ${ }^{16}$, Kurt Lewin's group dynamics ${ }^{21}$, the hermeneutic interpretative paradigm ${ }^{24}$ and the integrated model of change ${ }^{26}$, while ten studies did not mention the use of referentials ${ }^{15,17,20,23,29,31,34,36}$.

The actions developed were evaluated positively by both the elderly persons and those who performed the actions in all the studies analyzed. Even those that presented strategies with multimedia or marketing campaigns only, produced more modest impact evaluative results, but still described some benefit in the health promotion of the elderly persons.

\section{DISCUSSION}

The data demonstrated the versatility that health education actions present to health professionals as a strategy to promote the health of the elderly population, both in relation to the themes addressed and the strategies used.

The findings highlight the value of health education for this specific population, especially when the exchange of scientific and popular knowledge occurs; with the valorization of mutual knowledge, giving importance to the dialogue and increasing the power of comprehension of the elderly themselves, of others and the world, expanding the comprehension of diverse realities.

Health education for elderly persons is a topic of worldwide interest, since the current demographic and epidemiological changes highlight the need to value actions for this population, focusing on the development of autonomy, independence and improving quality of life through active and healthy aging.

The interest in producing studies on active aging in recent years is explained by the scenario of demographic transition, with an increasing proportion of elderly persons in the global and Brazilian population.

In Brazil, the recognition of this theme as a research priority was stated by the Ministry of Health $^{4}$, boosting scientific production in the area, in view of the need to identify and discuss the issues that relate to the new demands of society, as well as seek strategies that stimulate autonomy and improve the quality of life of the geriatric public.

In terms of the themes of educational actions with the elderly public, there was a predominance of topics such as healthy eating and physical activity, corroborated by a study that showed that health promotion was essential at all ages, and that for elderly persons its value is unquestionable, and furthermore that it is essential that elderly people create healthy lifestyle habits, particularly as regards their diet and exercise ${ }^{24}$

Chronic diseases such as hypertension and diabetes were also frequent themes, which may be explained by the higher prevalence of such diseases with advancing age ${ }^{36}$, and which therefore require special attention.

In a Brazilian study ${ }^{35}$, the choice of topics to be addressed with groups of elderly persons was decided mainly by the needs observed by health professionals, with the most addressed subjects being physical activity (90\%), diet (85\%) and lifestyle (75\%).

This highlights the need to transform the traditional manner of conducting health education groups ${ }^{35}$. It is necessary to go beyond recurrent 
biomedical topics such as illness, medications, complications and treatments, so that other topics such as leisure, the exchange of popular experiences and healthy community cooking can be addressed; among the many other possibilities to be applied in a health education group with elderly persons.

Some of the studies ${ }^{13,14,18,19,22,24,28-30,35}$ highlighted the importance of valuing the participation of the elderly persons in the actions, in order to seek out the topics of interest, as well as focusing on their previous experiences. When the elderly interact and the educational activity is based on their needs, it becomes more productive and provides more effective responses.

Health promotion presents us with challenges for the health education process, such as more dialogical and reflexive initiatives based on the practical experience of the actors ${ }^{37}$. The problematizing education defended by Paulo Freire is inserted as a reference for educational approaches through participatory strategies.

Some authors ${ }^{13,35,38}$ believe that participatory strategies and ludic approaches can contribute to healthy and active aging, as they are real spaces for the individual and collective expression of experiences and exchange of knowledge; as Paulo Freire argues, they become liberating and emancipating educational practices, as they focus on the experiences of the subjects, enabling free expression and addressing subjects of interest without disregarding prior knowledge, leading to the exchange of scientific and popular knowledge, rather than the vertical non-dialectical transmission of information.

Trying to break with the traditional aspect of educational workshops and allow one such program to be organized by its elderly participants was reported in a study, with resultant creativity, interest and commitment among the members, who unanimously elected this workshop as the best of those offered ${ }^{39}$.

Literature $^{21,39}$ points to the formation of groups and workshops with elderly persons as good strategies for establishing a process of coexistence among those involved, as well as the empowerment of their health, the participation of members, the practical implementation of the learning acquired, and the exchange of experiences and knowledge among the service users and health professionals.-

Of SUS professionals, the family health team nurse is especially responsible for educational actions, regulated by health promotion guidelines ${ }^{40}$; but it is also believed that it is the responsibility of the entire health team to work in an integral manner, focused on prevention and health promotion.

Such professionals are not, however, familiar with medical practices in prevention and health promotion, and thus is not best disposed to work with health education actions ${ }^{40,41}$.

This shortcoming emphasizes the importance of Permanent Health Education (PHE) for professionals working in primary care, already evidenced in 2017 by PRO EPS-SUS, established through Ordinance GM/MS No. 3,194, which considered the need to resume funding for and plan PHE actions at state and local levels ${ }^{42}$.

This ordinance aimed at financial transfers of funds to municipal districts for PHE actions in their territory aimed to stimulate, monitor and strengthen the professional qualifications of health workers, in order to transform health practices, towards the fulfillment of the fundamental principles of SUS, based on local realities and the collective analysis of work processes.

Thus, the government has realized that valuing the continuing education of health professionals can have returns in the context of improving the health situation of the population. This can be facilitated by the insertion of universities in health education actions in Basic Health Units (BHU), as well as in other places where the elderly are present, such as long-term care institutions.

The Ministry of Health and the Ministry of Education and Culture have been fostering the partnership between professional training institutions and health services, aiming to bring them closer to the SUS and the health needs of the Brazilian population, through programs that integrate higher 
education, community-service, as well as initiation schemes in work and research, with the participation of undergraduate students from various courses, teachers from educational institutions and health service professionals ${ }^{29}$.

Planning activities with elderly persons in an interdisciplinary manner is challenging for students, as the actions previously lacked a participatory and dynamic user approach, but by adopting these dialogical strategies, behavioral changes in group members were observed, with reported satisfaction from elderly persons, staff and all those involved in the process. It has been verified that the students/ teachers worked as facilitators of new possibilities, bringing another perspective to the needs of the group and the practices adopted for the care of geriatric users at the $\mathrm{BHU}^{29}$.

Despite this expansive process of population aging, the articles showed that studying better ways of implementing health education actions for the elderly public that can contribute to and stimulate self-care, autonomy and the improvement of quality of life are still required ${ }^{13,15,16,18,21,23,24,26,28}$.

It is recognized that educational interventions are key elements of health care delivery and that, based on the analysis of health policy experts and government agencies, such actions are cost-effective and have great potential to promote the physical and mental well-being of the elderly population ${ }^{43}$.

It is believed that health promotion and disease prevention strategies, associated with better care practices, can contribute to reducing the proportion of frail elderly persons, improving the health conditions of this group and reducing costs to the system; thus, participatory approaches are possibilities for implementing these preventive measures ${ }^{18}$.

The importance of actions of wellbeing and their impact on health costs in Brazil were mentioned in one study ${ }^{32}$. The analysis was based on the idea that the increase in the number of patients of various age groups, especially the elderly, led to greater demand for health services, with subsequently increased spending. Thus, prevention was considered the best investment. Strategies should therefore be created to delay illness and disability, aiming to increase the level of independence and autonomy of people.

Further studies need to be conducted to assess the impact of activities aimed at the elderly population, as well as to elucidate the need for new health education strategies guided by themes of interest for the elderly and which can contribute to improving their quality of life. Those that evaluate these actions and their impacts on the elderly population, as well as studies with evidence levels one and two, should also be encouraged.

Limitations of this study include: the failure to conduct an analysis of the effectiveness of the educational actions from the perception of the elderly persons, since the discussions presented are based mostly on the perception of professionals about the actions implemented. Furthermore, the scarcity of studies that discuss the effectiveness and efficiency of these actions for the health sector is also a challenge for scientific research.

\section{CONCLUSION}

It can be concluded that health education actions aimed at the elderly are based mainly on the promotion of healthy eating and physical exercise, and are carried out mainly by nurses from family health strategy teams and by community health agents, through group workshops and seminars/ lectures.

It was also found that actions to promote wellbeing focused on health education aimed at the elderly population were important strategies used by health professionals and/or university students to promote comprehensive care that favors healthy and active aging.

The innovation of the present study is based on the converging of the relevant thematic areas for research and care for the elderly, enabling readers to deepen their knowledge about the main themes and strategies used, as well as identify gaps for the development of new studies. 


\section{REFERENCES}

1. Brasil. Ministério da Saúde. Portaria MS/GM n ${ }^{\circ}$ 2.528, de 20 de outubro de 2006. Aprova a Política Nacional de Saúde da Pessoa Idosa. Diário Oficial da União. 19 out. 2006.

2. Falkenberg MB, Mendes TPL, Moraes EP, Souza EM. Health education and education in the health system: concepts and implications for public health. Ciênc Saúde Colet [Internet]. 2014;19(3):847-52. Disponível em: http://www.scielo.br/scielo.php?script=sci_ arttext\&pid=S1413-81232014000300847

3. Salci MA, Maceno P, Rozza SG, Silva DMGV, Boehs AE, Heidemann ITSB. Educação em saúde e suas perspectivas teóricas: algumas reflexões. Texto \& Contexto Enferm [Internet]. 2013 [acesso em 31 jan. 2018];22(1):224-30. Disponível em: http://www. scielo.br/scielo.php?script $=$ sci_arttext\&pid=S010407072013000100027\&lng=en

4. Roecker SE, Nunes EFPA, Marcon SS. O trabalho educativo do enfermeiro na Estratégia Saúde da Família. Texto \& Contexto Enferm [Internet]. 2013 [acesso em 25 jun. 2019];22(1):157-65. Disponível em: http://www.scielo.br/scielo.php?script $=$ sci arttext\&pid=S0104-07072013000100019\&lng=en

5. Oliveira MR, Veras RP, Cordeiro HA, Pasinato MT. A mudança de modelo assistencial de cuidado ao idoso na Saúde Suplementar: identificação de seus pontoschave e obstáculos para implementação. Physis [Internet]. 2016 [acesso em 13 maio 2018];26(4):138394. Disponível em: http://www.scielo.br/scielo. php?pid $=$ S0103-73312016000401383\&script $=$ sci_ abstract\&tlng $=\mathrm{pt}$

6. Gautério DP, Vidal DAS, Barlem JGT, Santos SSC. Action by nurses to educate older adults: the family health strategy. Rev Enferm UERJ [Internet]. 2013 [acesso em 13 maio 2018];21(6):824-8. Disponível em: https://www.e-publicacoes.uerj.br/index.php/ enfermagemuerj/article/view/12302

7. Nunes JM, Oliveira EN, Machado MFAS, Costa PNP, Vieira NFC. Ser mulher e participar de grupo educativo em saúde na comunidade: motivações e expectativas. Rev Enferm UERJ [Internet]. 2014 [acesso em 03 jun. 2018];22(1):123-8. Disponível em: http://www.facenf.uerj.br/v22n1/v22n1a19.pdf

8. Leite CT, Vieira RP, Machado CA, Quirino GS, Machado MFAS. Prática de educação em saúde percebida por escolares. Cogitare Enferm [Internet]. 2014 [acesso em 03 jun. 2018];19(1):13-9. Disponível em: https://revistas.ufpr.br/cogitare/article/ view/35925/22157
9. Brasil. Ministério da Saúde. Agenda de Prioridades de Pesquisa do Ministério da Saúde - APPMS [Internet]. Brasília, DF: MS; 2018 [acesso em 10 fev. 2018]. Disponível em: http://bvsms.saude.gov.br/bvs/ publicacoes/agenda_prioridades_pesquisa_ms.pdf

10. Mendes KDS, Silveira RCCP, Galvão CM. Revisão Integrativa: método de pesquisa para a incorporação de evidências na saúde e na enfermagem. Texto Contexto Enferm [Internet]. 2008 [acesso em 25 fev. 2018];17(4):758-64. Disponível em: http://www.scielo.br/scielo.php?script=sci_ arttext\&pid=S0104-07072008000400018

11. Brasil. Decreto Presidencial no 8.114, de 30 de setembro de 2013. Estabelece o compromisso nacional para o envelhecimento ativo e institui Comissão Interministerial para monitorar e avaliar ações em seu âmbito e promover a articulação de órgãos e entidades públicos envolvidos em sua implementação. Diário Oficial da União. 01 out. 2013.

12. Sampaio RF, Mancini MC. Estudos de revisão sistemática: um guia para síntese criteriosa da evidência científica. Rev Bras Fisioter [Internet]. 2007 [acesso em 14 de abr. 2018];11(1):83-9. Disponível em: http://www.scielo.br/pdf/rbfis/v11n1/12.pdf

13. Mendonça ET, Aires LFA, Amaro MO, Moreira TR, Henriques BD, Almeida LC, et al. A experiência de oficinas educativas com idosos: (re)pensando práticas à luz do pensamento freireano. Rev Aten Prim Saúde [Internet]. 2013 [acesso em 16 abr. 2018];16(4):479-80. Disponível em: http://ojs2.ufjf.emnuvens.com.br/aps/ article/view/15199

14. Nogueira ALG, Munari DB, Santos LF, Oliveira LMAC, Fortuna CM. Fatores terapêuticos identificados em um grupo de promoção da saúde de idosos. Rev Esc Enferm USP [Internet]. 2013 [acesso em 17 abr. 2018];47(6):1352-8. Disponível em: http://www.scielo.br/pdf/reeusp/v47n6/0080-6234reeusp-47-6-01352.pdf

15. Evers U, Jones SC, Iverson D, Caputi P. 'Get Your Life Back': process and impact evaluation of an asthma social marketing campaign targeting older adults. BMC Public Health [Internet]. 2013 [acesso em 16 abr. 2018];13(1):1-12. Disponível em: https://bmcpublichealth.biomedcentral.com/ articles/10.1186/1471-2458-13-759

16. Bhurosy T, Jeewon R. Effectiveness of a theorydriven nutritional education program in improving calcium intake among older Mauritian adults. Scient World J [Internet]. 2013 [acesso em 24 abr. 2018];2013:1-16. Disponível em: https://www.ncbi. nlm.nih.gov/pmc/articles/PMC3888757/ 
17. Chung LMY, Chung JWY. Effectiveness of a food education program in improving appetite and nutritional status of elderly adults living at home. Asia Pacc J Clinl Nutr [Internet]. 2014 [acesso em 01 maio 2018];23(2):315-20. Disponível em: https://pdfs.semanticscholar. org/57bf/339f39c432f4224cb21f313b9e7b586bbd15.pdf

18. Ferretti F, Gris A, Mattielo D, Teo CPA, Sá C. Impacto de programa de educação em saúde no conhecimento de idosos sobre doenças cardiovasculares. Rev Salud Pública [Internet]. 2014 [acesso em 29 abr. 2018];16(6):807-20.Disponível em: https://www. scielosp.org/article/ssm/content/raw/?resource_ssm_ path $=/$ media/assets/rsap/v16n6/v16n6a01.pdf

19. Janini JP, Bessler D, Vargas AB. Educação em saúde e promoção da saúde: impacto na qualidade de vida do idoso. Saúde Debate [Internet]. 2015 [acesso em 03 maio 2018];39(105):480-90. Disponível em: http://www.scielo.br/pdf/sdeb/v39n105/0103-1104sdeb-39-105-00480.pdf

20. Sink KM, Espeland MA, Castro CM, Church T, Cohen R, Dodson JA. Effect of a 24-month physical activity intervention vs health education on cognitive outcomes in sedentary older adults: the LIFE randomized trial. JAMA [Internet]. 2015 [acesso em 12 maio 2018];314(8):781-90. Disponível em: https:// www.ncbi.nlm.nih.gov/pubmed/26305648

21. Machado ARM, Santos WS, Dias FA, Tavares DMS, Munari DB. Potencializando um grupo de terceira idade de uma comunidade rural. Rev Esc Enferm USP [Internet]. 2015 [acesso em 11 maio 2018];49(1):96-103. Disponível em: http://www.scielo.br/pdf/reeusp/ v49n1/pt_0080-6234-reeusp-49-01-0096.pdf

22. Almeida LFF, Freitas EL, Salgado SML, Gomes IS, Fransceschini SCC, Ribeiro AQ. Projeto de intervenção comunitária "Em Comum-Idade": contribuições para a promoção da saúde entre idosos de Viçosa, MG, Brasil. Ciênc Saúde Colet [Internet]. 2015 [acesso em 03 maio 2018];20(12):3763-74.

Disponível em: https://www.scielosp.org/article/ssm/ content/raw/?resource_ssm_path=/media/assets/csc/ v20n12/1413-8123-csc-20-12-3763.pdf

23. Caprara MG, Fernández-ballesteros R, Alessandri G. Promoting aging well: evaluation of vital-agingmultimedia program in Madrid, Spain. Health Promot Int [Internet]. 2016 [acesso em 12 maio 2018];31(3):515-22. Disponível em: https://www.ncbi. nlm.nih.gov/pubmed/25784303

24. Sousa SEM, Oliveira MCC. Viver a (e para) aprender: uma intervenção-ação para a promoção do envelhecimento ativo. Rev Bras Geriatr Gerontol [Internet]. 2015 [acesso em 11 maio 2018];18(2):40515. Disponível em: http://www.scielo.br/pdf/rbgg/ v18n2/1809-9823-rbgg-18-02-00405.pdf
25. Cecílio A, Oliveira JM. Educação nutricional para idosos institucionalizados no recanto Nossa Senhora do Rosário em Limeira, SP. Estud Interdiscip Envelhec [Internet]. 2015 [acesso em 14 maio 2018];20(2):413-26. Disponível em: https://seer.ufrgs. br/RevEnvelhecer/article/view/40475/35447

26. Luten KA, Reijneveld AS, Dijkstra A, Winter AF. Reach and effectiveness of an integrated communitybased intervention on physical activity and healthy eating of older adults in a socioeconomically disadvantaged community. Health Educ Res [Internet]. 2015 [acesso em 20 maio 2018];31(1):98106. Disponível em: https://www.ncbi.nlm.nih.gov/ pmc/articles/PMC4883033/

27. Lucena ALR, Freitas FFQ, Vieira KFL, Matos SDO. Ensinando e aprendendo com idosos: relato de experiência. J Res Fundam Care [Internet]. 2016 [acesso em 13 maio 2018];8(2):4131-41.

Disponível em: https://www.researchgate.net/ publication/301333342_Ensinando_e_aprendendo_ com_idosos_relato_de_experiencia_Teaching_and_ learning_with_the_elderly_experience_report

28. Munhoz OL, Ramos TK, Moro B, Timm MS, Venturini L, Cremonese L, et al. Oficina bingo da saúde: uma experiência de educação em saúde com grupos de idosos. Rev Min Enferm [Internet]. 2016 [acesso em 16 maio 2018];20:e968 [5 p.]. Disponível em: http://www.reme.org.br/artigo/detalhes/1104

29. Barbosa AS, Andrade GCL, Pereira CO, Falcão IV. A interdisciplinaridade vivenciada em um grupo de idosos de uma unidade de saúde da família do Recife. Revista APS [Internet]. 2016 [acesso em 22 maio 2018];19(2):315-20. Disponível em: http://ojs2.ufjf. emnuvens.com.br/aps/article/view/15414

30. Nascimento MM, Ramos LS. Educação médica e interdisciplinaridade: um relato de experiência com idosos residentes na comunidade. Arq Ciênc Saúde UNIPAR [Internet]. 2016 [acesso em 22 maio 2018];20(3):205-9. Disponível em: https://www.researchgate. net/publication/317253673_EDUCACAO_ MEDICA_E_INTERDISCIPLINARIDADE_ UM_RELATO_DE_EXPERIENCIA_COM_ CIDADAOS_IDOSOS

31. Lopes MA, Marchesan M, Krug RR, Mazo GZ. Aspectos pedagógicos relevantes de uma aula para a adoção e a permanência em programas de atividade física percebidos por idosas longevas. Estud Interdiscip Envelhec [Internet]. 2016 [acesso em 16 maio 2018];21(1),55-70. Disponível em: https://seer. ufrgs.br/RevEnvelhecer/article/view/50486/40712 
32. Sá PHVO, Cury GC, Ribeiro LCC. Atividade física de idosos e a promoção da saúde nas unidades básicas. Trab Educ Saúde [Internet]. 2016 [acesso em 13 maio 2018;14(2):545-58. Disponível em: http://www.scielo.br/scielo.php?pid=S1981$77462016005002104 \&$ script $=$ sci_abstract $\&$ tlng $=$ pt

33. Jih J, Gem L, Woo K, Tsoh JY, Stewart S, Gildengorin G. Educational interventions to promote healthy nutrition and physical activity among older Chinese Americans: a clusterrandomized trial. Am J Public Health [Internet]. 2016 [acesso em 01 jun. 2018];106(6):1092-8. Disponível em: https://www.ncbi.nlm.nih.gov/pmc/ articles/PMC4880259/

34. Amthauer C, Falk JW. Discursos dos profissionais de saúde da família na ótica da assistência à saúde do idoso. J Res Fundam Care Online [Internet]. 2017 [acesso em 28 maio 2018];9(1):99105. Disponível em: https://www.researchgate. net/publication/312204417_Discursos_dos_ profissionais_de_saude_da_familia_na_otica_ da_assistencia_a_saude_do_idoso_Speeches_ of_family_health_professionals_in_optics_of_ assistance_to_the_elderly

35. Mendonça FTNF, Santos AS, Buso ALZ, Malaquias BSS. Health education with older adults: action research with primary care professionals. Rev Bras Enferm [Internet]. 2017 [acesso em 27 maio 2018];70(4):792-9. Disponível em: http://www.scielo.br/scielo.php?pid=S0034$71672017000400792 \&$ script $=$ sci_abstract

36. Santos SLF, Alves HHS, Oliveira RA, Paiva CEQ, Pessoa CV, Barros KBNT. Relato de experiência sobre educação em saúde em idosos: percepção dos discentes. Revista APS [Internet]. 2017 [acesso em 15 jun. 2018];20(3):450-5. Disponível em: http://ojs2.ufjf. emnuvens.com.br/aps/article/view/16054
37. Silva CS, Bodstein RCA. Referencial teórico sobre práticas intersetoriais em Promoção da Saúde na Escola. Ciênc Saúde Colet [Internet]. 2016 [acesso em 15 jun. 2019];21(6):1777-88. Disponível em: https:// doi.org/10.1590/1413-81232015216.08522016

38. Freire P. Educação como prática da liberdade. $34^{\mathrm{a}}$ ed. São Paulo: Paz e Terra; 2011.

39. Andrade TP, Mendonça BPCK, Lima DC, Alfenas IC, Bonolo PF. Projeto conviver: estímulo à convivência entre idosos do Catete, Ouro Preto, MG. Rev Bras Educ Méd [Internet]. 2012 [acesso em 06 jul. 2019];36(1):81-5. Disponível em: http://www.scielo. br/pdf/rbem/v36n1s1/v36n1s1a11.pdf

40. Roecker S, Budó MLD, Marcon SS. Trabalho educativo do enfermeiro na Estratégia Saúde da Família: dificuldades e perspectivas de mudanças. Rev Esc Enferm USP [Internet]. 2012 [acesso em 15 jul. 2019];46(3):641-9. Disponível em: http://www.scielo. br/pdf/reeusp/v46n3/16.pdf

41. Gonçalves RJ, Soares RA, Troll T, Cyrino EG. Ser médico no PSF: formação acadêmica, perspectivas e trabalho cotidiano. Rev Bras Educ Méd [Internet]. 2009 [acesso em 07 jul. 2019];33(3):382-92. Disponível em: http://www.scielo.br/scielo.php?pid=S0100$55022009000300009 \&$ script $=$ sci_abstract\&tlng=pt

42. Brasil. Portaria GM/MS no 3.194, de 28 de novembro de 2017. Dispõe sobre o Programa para o Fortalecimento das Práticas de Educação Permanente em Saúde no Sistema Único de Saúde - PRO EPS-SUS. Nov. 2017. Disponível em: http://www.cosemsrn.org. br/wp-content/uploads/2017/12/ok-portaria3194.pdf

43. Clark F, Jackson J, Carlson M, Chou CP, Cherry BJ, Jordan-Marsh M, et al. Effectiveness of a lifestyle intervention in promoting the well-being of independently living older people: results of the Well Elderly 2 Randomised Controlled Trial. J Epidemiol Community Health [Internet]. 2012 [acesso em 04 jul. 2019];66(9):782-90. Disponível em: https://www.ncbi. nlm.nih.gov/pubmed/21636614 